${ }^{3}$ Infectious and Liver Diseases Department, Medical University of Lodz

\title{
The belief of control and engagement in health related behaviours in the groups of adolescents with type 1 diabetes and excess body weight
}

\section{ABSTRACT}

Introduction. The aim of this study is to assess the level of health-related behaviours among adolescents with type 1 diabetes and excess body weight, and the correlation occurring between the locus of control and the intensity of selected health-related behaviours among the respondents.

Material and methods. The study was conducted among patients of the Diabetes Clinic of the University Clinical Hospital No. 1 in Lodz and the Outpatient Clinic for Obesity Prevention and Therapy, Polish Mother's Memorial Hospital - Research Institute in Lodz. The age of the patients ranged from 12 to 20 . The measurement of the variables was done utilising three methods: the Health Behaviour Inventory (IZZ), the Delta questionnaire to measure the locus of control and a survey of the author's own design.

Results. The results indicate, inter alia, that the surveyed young people suffering from type 1 diabetes or excess body weight do not engage in health-related behaviours more intensely than healthy individuals, though, the belief of having influence on their lives (the internal locus of control) dominates among them. What is more, a strong need for social approval is correlated, in the study groups, with the level of health-

Address for correspondence:

dr n. hum. Joanna Miniszewska

Zakład Psychologii Zdrowia, Instytut Psychologii, Uniwersytet Łódzki

e-mail: aysa@poczta.onet.pl

Clinical Diabetology 2016, 5, 5, 152-158

DOI: $10.5603 /$ DK.2016.0027

Received: 27.09.2016

Accepted: 02.01.2017 related behaviours, which can suggest that the average level of health-related behaviours stems from a desire to present oneself in a best possible light.

Conclusion. Young people with type 1 diabetes and people with excess body weight present a comparable, unfortunately only average, level of health-related behaviours. Results suggest that the respondents probably tried to present themselves in a best possible light and the outcomes obtained, not higher than average, can be overstated, as compared with the actual level of health-related behaviours. (Clin Diabetol 2016; 5, 5: 152-158)

Key words: health behaviours, locus of control, excess body weight, diabetes

\section{Introduction}

Comprehensive treatment of chronic diseases requires lifestyle changes and the introduction of new health behaviours $[1,2]$. In the treatment of type 1 diabetes, as well as in activities aimed at reducing excess body weight, health-related recommendations are associated first of all with diet and regular exercises. It is recognized that the above-mentioned behaviours may directly affect health (through, e.g. reducing the level of glucose in the blood) and reduce the risk of developing serious complications [3-9].

The modern models explaining human behaviour emphasize the importance of individual factors determining the initiation of an action and its continuation despite the existing difficulties. One such factor is the locus of control [9-12]. The locus of control, understood 
as one of the dimensions of human personality, refers to the way in which individuals perceive the causality of the correlation between their own behaviours and their consequences $[1,7,9,13-16]$. The detailed scope of the locus of control has also been developed on the basis of health psychology, relating directly to the health, or health locus of control, which explains how the location of control affects the activities of human health. There are three types of health locus of control, i.e. internal (i.e. the belief that one can influence one's own health and that health depends on one's own actions), external (the belief that only other people, e.g. medical staff, can decide on human health) and a coincidence (whether a human becomes ill or not is simply the result of coincidence). Most studies on the problems of the correlation between health-related behaviours and the locus of control show that the internal locus of control promotes health, as it causes taking on greater responsibility for it. However, there are also studies showing that different types of health locus of control may be more favourable in some and harmful in other circumstances. When initiating new behaviours, it is favourable to be convinced of the internal locus of control, but in the case of chronic diseases, good results for the improvement of health are usually the result of being convinced of the decisive influence of medical staff, and a strong internal control can be even harmful $[9,17]$. However, it turns out that the health locus of control itself to a small extent predicts the intensity of health-related behaviours, as health valuation, among others, is an important mediator. It has been proven that in the groups that do not recognize health as an important value in life, for example, among young people and those generally feeling healthy, the internal locus of control does not affect the increased frequency of health-related behaviours [18]. For this reason, the presented analyses do not refer to a specific health locus of control, but to the generalized locus of control.

\section{Aim of the study}

Engagement in health-related behaviours by people with somatic diseases is the way to relative autonomy and reducing any risk of the disease complications. Engaging in behaviours conducive to health can slow the progression of disease processes and prevent relapses [19-21].The importance of health-related behaviours is also stressed in the prevention of morbidity and mortality [19-21]. Therefore, the search for factors that can increase the likelihood of engaging in behaviours conducive to health is extremely important. Their identification can be used to develop programmes that support the standard therapeutic procedures.
The presented study attempts to:

- assess the level of health-related behaviours in the studied groups, i.e. among youth with type 1 diabetes and among young people with excess body weight;

- estimate the intensity of the locus of control in the studied groups;

- answer the question whether the generalized locus of control is correlated with engagement in health-related behaviours, and if so, what is the nature of this correlation.

Based on the literature of the issue, the following hypotheses have been formulated:

- young people with type 1 diabetes and excess body weight people have a higher than average level of health-related behaviours;

- the studied groups are dominated by the internal health locus of control;

- the internal health locus control is correlated with more frequent engagement in health-related behaviours in the studied groups.

\section{Material and methods}

The study was conducted on a group of 64 people that are patients at the Diabetes Clinic of the University Clinical Hospital No. 1 in Lodz and the Outpatient Clinic for Obesity Prevention and Therapy, Polish Mother's Memorial Hospital - Research Institute in Lodz (Table 1). Half of them $(n=32)$ had been diagnosed with type 1 diabetes, while the second part $(n=32)$ was treated because of excess body weight (the average BMI for this group is $M=30.5 ; S D=5.42 ;$ Min = 25.4; $\operatorname{Max}$ $=46.7$ ). Only those individuals who do not meet the criteria of both excess body weight and diabetes were included in the study. The study was approved by the Bioethical Committee at University of Lodz (No. KBBN/ II/15/2013). The participants were informed about the aim, the subject matter and course of the study and consented to it.

The following tools were used:

- Health Behaviour Inventory (IZZ) by Juczynski. The inventory consists of 24 items associated with different types of health-related behaviours. The tool enables the determination of the overall rate of health-related behaviours and the degree of intensity of the four categories of behaviours: proper nutrition (including the consumption of fruit, vegetables and wholemeal bread), prevention culture (adherence to prescriptions and obtaining information on health and disease), health-related practices (daily sleep and leisure habits and physical activity); positive mental attitude (avoiding strong emotions, stress, depress- 
Table 1. Characteristics of the study group

\begin{tabular}{|c|c|c|c|c|c|c|}
\hline \multirow[b]{2}{*}{ Sex } & \multicolumn{2}{|c|}{$\begin{array}{c}\text { Diabetic group body } \\
\text { weight group }\end{array}$} & \multicolumn{2}{|c|}{ Excess } & \multicolumn{2}{|c|}{ Total } \\
\hline & $\mathrm{N}$ & $\%$ & $\mathrm{~N}$ & $\%$ & $\mathbf{N}$ & $\%$ \\
\hline Boys & 15 & 47 & 13 & 41 & 28 & 56 \\
\hline Girls & 17 & 53 & 19 & 59 & 36 & 47 \\
\hline Age & Years old & & Years old & & Years old & \\
\hline Mean & 15 & & 16 & & 16 & \\
\hline Min & 12 & & 12 & & 12 & \\
\hline Max & 20 & & 20 & & 20 & \\
\hline Dominant & 14 & 25 & 19 & 19 & 14 & 17 \\
\hline Median & 15 & & 17 & & & \\
\hline
\end{tabular}

Table 2. Increased intensity of health-related behaviours and their components in the studied groups

\begin{tabular}{|c|c|c|c|c|c|c|}
\hline \multirow[t]{2}{*}{ Health-related behaviours } & \multicolumn{2}{|c|}{$\begin{array}{c}\text { The group suffering } \\
\text { from type } 1 \\
\text { diabetes }(\mathrm{N}=32)\end{array}$} & \multicolumn{2}{|c|}{$\begin{array}{l}\text { The group with excess } \\
\text { body weight }(\mathrm{N}=32)\end{array}$} & \multirow[b]{2}{*}{$\mathbf{t}$} & \multirow[b]{2}{*}{$\mathbf{p}$} \\
\hline & M & SD & M & SD & & \\
\hline Overall rate of health-related behaviours & 84.69 & 11.96 & 84.91 & 13.219 & 0.01 & 0.992 \\
\hline Positive nutrition habits & 3.49 & 0.81 & 3.79 & 0.77 & 1.49 & 0.141 \\
\hline Preventive behaviours & 3.51 & 0.66 & 3.37 & 0.84 & 0.75 & 0.458 \\
\hline Positive mental attitude & 3.57 & 0.58 & 3.50 & 0.67 & 0.40 & 0.693 \\
\hline Health-related practices & 3.54 & 0.56 & 3.46 & 0.66 & 0.51 & 0.612 \\
\hline
\end{tabular}

ing situations). The inventory has satisfactory psychometric properties [22];

- The "Delta" Questionnaire for the Measurement of Control by Drwal. The tool measures the generalized sense of control, recognized as a dimension of personality. It consists of 24 affirmative sentences evaluated by the participants as true or false. Out of all the statements, 14 belong to the LOC Scale, defining the locus of control as internal (high scores) or external (low scores). The remaining 10 form the $\mathrm{K}$ (Lie) Scale. A high score on this scale indicates the respondent's trend to present oneself in excessively favourable light. Statistical analyses of the LOC Scale of the "Delta" questionnaire have shown that it has sufficient reliability and validity for use in the study group and intergroup comparisons [13];

- the survey of own design, including a fiche, questions about having type 1 diabetes - duration of the disease, treatment and a section on behaviours conductive to health - level of physical activity during the week, types of meals, drinking alcohol and smoking cigarettes.

\section{Results}

Level of health-related behaviours

The first stage of the analysis of the results was to estimate the level of health-related behaviours. Results are presented in Table 2.

It has been found that adolescents with type 1 diabetes and with excess body weight or obesity did not differ from each other in terms of different types of health-related behaviours. The average results of the overall rate of health-related behaviours among people with diabetes and excess body weight are within the range of average results (i.e. corresponding to the value of 6 sten $^{1}$, in accordance with the standards developed by Juczynski [22]). The average values of individual dimensions of the Health Behaviour Inventory are lower in the group than the value obtained by the adult diabetics in the study by Juczynski [22], and higher in comparison with the results obtained by

${ }^{1}$ It is a unit of psychological scale normalized so that the mean value of population was 5.5 , and the standard deviation is 2 . The scale consists of 10 units ( 1 to 4 means low scores, 5 to 6 - average, 7 to 10 high scores) [Hornowska E. Testy psychologiczne: teoria i praktyka. Scholar, Warszawa 2007]. 
Table 3. Intensity of health-related and anti-health behaviours in the study groups

\begin{tabular}{|c|c|c|c|c|c|c|}
\hline & \multicolumn{2}{|c|}{$\begin{array}{l}\text { The group suffering from } \\
\text { type } 1 \text { diabetes }(N=32)\end{array}$} & \multicolumn{2}{|c|}{$\begin{array}{l}\text { The group with excess } \\
\text { body weight }(\mathrm{N}=32)\end{array}$} & \multirow[b]{2}{*}{$\mathbf{t}$} & \multirow[b]{2}{*}{$\mathbf{p}$} \\
\hline & $\mathbf{M}$ & SD & $\mathbf{M}$ & SD & & \\
\hline Health-related behaviours & 22.06 & 2.92 & 21.69 & 3.61 & 0.46 & 0.649 \\
\hline Active leisure time & 3.25 & 0.80 & 2.72 & 0.77 & 2.70 & 0.009 \\
\hline Consumption of fruit and vegetables & 4.34 & 0.60 & 4.19 & 0.93 & 0.80 & 0.428 \\
\hline Consumption of fish & 2.66 & 0.70 & 2.84 & 0.85 & -0.97 & 0.338 \\
\hline Consumption of poultry & 3.66 & 0.79 & 3.63 & 1.10 & 0.13 & 0.896 \\
\hline Consumption of dark bread & 3.78 & 1.31 & 3.75 & 1.39 & 0.09 & 0.927 \\
\hline Drinking still water & 4.38 & 1.16 & 4.56 & 1.01 & -0.69 & 0.493 \\
\hline Anti-health behaviours & 15.50 & 3.33 & 13.94 & 3.77 & 1.76 & 0.084 \\
\hline Drinking carbonated beverages & 2.84 & 1.44 & 2.44 & 1.41 & 1.14 & 0.259 \\
\hline Consumption of sweets & 3.44 & 1.11 & 2.66 & 1.10 & 2.84 & 0.006 \\
\hline Consumption of salty snacks & 2.75 & 1.16 & 2.25 & 1.05 & 1.81 & 0.076 \\
\hline Smoking cigarettes & 1.38 & 0.91 & 1.31 & 0.70 & 0.31 & 0.758 \\
\hline Drinking alcohol & 1.44 & 0.76 & 1.59 & 0.88 & -0.76 & 0.448 \\
\hline
\end{tabular}

Table 4. Mean and standard deviation of the general level of health-related behaviours and their components in the groups of girls and boys

\begin{tabular}{|c|c|c|c|c|c|c|}
\hline & \multicolumn{2}{|c|}{ Girls $(N=36)$} & \multicolumn{2}{|c|}{ Boys $(\mathrm{N}=28)$} & \multirow[b]{2}{*}{$\mathbf{t}$} & \multirow[b]{2}{*}{$\mathbf{p}$} \\
\hline & M & SD & $M$ & SD & & \\
\hline Health-related behaviours & 89.11 & 11.46 & 79.25 & 14.78 & 3.38 & $0.001 * *$ \\
\hline Positive nutrition habits & 3.90 & 0.75 & 3.31 & 0.74 & 3.12 & $0.003^{*}$ \\
\hline Preventive behaviours & 3.70 & 0.70 & 3.11 & 0.68 & 0.37 & $0.001 * *$ \\
\hline Positive mental attitude & 3.56 & 0.51 & 3.51 & 0.76 & 0.30 & 0.762 \\
\hline Health-related practices & 3.70 & 0.57 & 3.24 & 0.57 & 3.21 & $0.002^{*}$ \\
\hline
\end{tabular}

${ }^{*} p<0.01 ;{ }^{* *} p<0.001$

Zadworna-Cieslak and Oginska-Bulik [23] in a population of healthy young people aged 17-19.

Table 3 shows the average level of health-related and anti-health behaviours for the study groups, as determined on the basis of the results of the survey of own design.

There were no significant differences in the general level of pro- and anti-health behaviours among young people with excess body weight and young people with type 1 diabetes. The study groups differ, however, in respect of certain types of behaviours. Adolescents with diabetes are significantly more likely to undertake physical activity during their leisure time $(p<0.01)$. At the same time, they more often consume sweets $(p<0.01)$ and salty snacks (this result is not statistically significant).

The results of the analysis indicate that the average level of health-related behaviours in the group of girls and boys differ significantly ( $p<0.001)$. The differences relate to the overall rate of health-related behaviours and their three components: positive consumption habits $(p<0.01)$, preventive behaviours $(p<0.001)$ and health-related practices $(p<0.01)$. The surveyed girls, more likely than boys, engage in these health-related behaviours. In contrast, the youth of both sexes did not differ in terms of positive mental attitudes ( $p>0.05)$ (Table 4).

\section{Locus of control}

The next stage of the analyses is to check the intensity of the individual dimensions of the locus of control in the study groups. It was found that the study groups of adolescents are not different from each other in terms of the locus of control $(p<0.05)$. Both groups are dominated by the internal locus of control. The results are presented in Table 5 .

The results obtained in the Delta Questionnaire indicate that the average intensity of the internal locus 
Table 5. Locus of control (LOC) in the study groups

\begin{tabular}{|c|c|c|c|c|c|c|}
\hline \multirow[t]{2}{*}{ Locus of control } & \multicolumn{2}{|c|}{$\begin{array}{l}\text { The group suffering } \\
\text { from diabetes }(\mathrm{N}=32)\end{array}$} & \multicolumn{2}{|c|}{$\begin{array}{l}\text { The group with excess } \\
\text { body weight }(N=32)\end{array}$} & \multirow[b]{2}{*}{$t$} & \multirow[b]{2}{*}{$p$} \\
\hline & $\mathbf{M}$ & SD & $\mathbf{M}$ & SD & & \\
\hline Internal LOC & 10.09 & 2.89 & 9.12 & 2.71 & 1.38 & 0.171 \\
\hline External LOC & 3.91 & 2.89 & 4.88 & 2.71 & -1.38 & 0.171 \\
\hline Lie Scale & 2.62 & 1.62 & 2.41 & 1.56 & 0.55 & 0.585 \\
\hline
\end{tabular}

Table 6. Correlation between the locus of control (LOC) and health-related behaviours

\begin{tabular}{lccccccc}
\hline \multicolumn{1}{l}{ The group suffering from diabetes } & \multicolumn{1}{l}{$\begin{array}{l}\text { Overall rate of } \\
\text { health-related } \\
\text { behaviours }\end{array}$} & $\begin{array}{c}\text { Positive } \\
\text { consumption } \\
\text { habits }\end{array}$ & $\begin{array}{c}\text { Preventive } \\
\text { behaviours }\end{array}$ & $\begin{array}{c}\text { Positive } \\
\text { mental } \\
\text { attitude }\end{array}$ & $\begin{array}{c}\text { Health- } \\
\text {-related } \\
\text { practices }\end{array}$ & $\begin{array}{c}\text { Pro-health } \\
\text { behaviours }\end{array}$ & $\begin{array}{c}\text { Anti-health } \\
\text { behaviours }\end{array}$ \\
\hline Internal LOC & -0.011 & -0.106 & 0.290 & -0.080 & -0.159 & 0.156 & 0.216 \\
External LOC & 0.011 & 0.106 & -0.290 & 0.080 & 0.159 & -0.156 & -0.216 \\
K Scale & $0.501^{* *}$ & $0.377^{*}$ & $0.392^{*}$ & 0.344 & $0.429^{*}$ & 0.251 & -0.173 \\
\hline The group with excess body weight & & & & & & & \\
\hline Internal LOC & 0.113 & 0.332 & 0.152 & -0.043 & -0.160 & $0.400^{*}$ & -0.271 \\
External LOC & -0.113 & -0.332 & -0.152 & 0.043 & 0.160 & $-0.400^{*}$ & 0.271 \\
K Scale & $0.357^{*}$ & 0.212 & $0.374^{*}$ & 0.185 & 0.310 & -0.068 & -0.226 \\
\hline
\end{tabular}

*Correlation significant at the 0.05 level (two-way); ** correlation significant at the 0.01 level (two-way)

of control is in the high range of results in both groups, while the average intensity of the external LOC is within low results. In both groups, the results of the Lie Scale are at the average level.

\section{Locus of control and the intensity of health-related behaviours}

The last stage of the analysis of the results was to check the inter-correlations between the locus of control and the intensity of health-related behaviours in the study groups (Table 6). And so, in the group of adolescents with diabetes there was no significant correlation between the locus of control and the health-related behaviours. A moderate positive correlation has been shown between the Lie Scale and the general rate of health-related behaviours, positive consumption habits, preventive behaviours and pro-health behaviours. This suggests that young people in this group could, due to the high need for social approval, try to present themselves in a best possible light. It is probable that the results, in terms of the mentioned types of healthrelated behaviours, are overstated.

Among adolescents with excess body weight, the sense of internal locus of control correlated positively with pro-health behaviours. In other words, the greater the belief of influence, the more frequent the involve- ment in health-related behaviours. At the same time, it was found that the results on the Lie Scale correlate positively with the general indicator of health-related behaviours and preventive behaviours. All of the mentioned correlations are moderate.

\section{Discussion}

Young people with type 1 diabetes and people with excess body weight show, contrary to our expectations, only the average intensity of health-related behaviours and do not differ from each other in terms of the exhibited level of health-related behaviours. Similar results were obtained by Janowski et al. [1] - in their study patient groups also did not differ in terms of the intensity of health-related behaviours. The analysis of the results obtained in the IZZ questionnaire indicates that young people with excess body weight focus the most on proper consumption habits, and the ones with diabetes on positive mental attitudes, preventive behaviours and health-related practices. It can be presumed that people from both groups focus more attention on the types of behaviours that are directly related to their current state of health. People with obesity try to eat healthy food, while people with diabetes strive to better cope with negative emotions, mainly their fear related to the 
disease, as well as frequently contact their doctor to control the course of treatment. They also use more diverse health-related practices, indicating that their care about their health in a more holistic manner (among others, they practice proper sleep hygiene, avoid colds and do not overwork).

Based on the responses to the questionnaire on the frequency of consumption of specific foods, generally considered healthy or unhealthy, it can be stated that young people with diabetes adhere to dietary recommendations less strict than those with excess body weight. Obese people are less likely to reach for sweets and salty snacks than their peers with type 1 diabetes. These results are consistent with the results of other studies. It has been shown that young people with excess body weight, due to their increased interest in diet and weight loss, have a greater knowledge of the principles of proper nutrition and are also more likely to adhere to them than their peers with normal weight $[24,25]$. Low effectiveness in reducing weight, according to the authors, is correlated with the presence of other negative habits, such as: eating irregular meals or not eating breakfast [24]. The results related to physical activity suggest that diabetics spend more time on active leisure than people with excess body weight and obesity. Presumably, people with diabetes play sports because it is recommended as a method of treatment. The research conducted by the team of Malkowska-Szkutnik [26] also showed that the self-esteem of own physical fitness is extremely important to young people with diabetes and it is one of the determinants of self-esteem. By contrast, the low level of physical activity among people with excess body weight is both an important cause and a consequence of the overweight or obesity [27].

Gender significantly differentiates the level of health-related behaviours among young people. Girls showed significantly higher levels of health-related behaviours than boys. This confirms previous research on health-related behaviours [23].

The results revealed no significant differences between the groups in terms of the sense of the locus of control. Young people, as expected, were dominated by the internal locus of control.

The mean values indicate that the average level of the internal locus of control was higher in patients with diabetes than among adolescents with excess body weight. This trend would probably prove to be statistically significant if the study involved more respondents.

In the group with type 1 diabetes, higher overall rate of health-related behaviours and more positive consumption habits were significantly correlated only with a greater need for social approval. The engagement in health-related behaviours was related to the locus of control only in patients with excessive body weight. This result is inconsistent with the authors' assumptions and inconsistent with the results of other reports in which the conviction of influence was related both to health-related behaviours and adherence to medical recommendations in the groups of people with diabetes $[3,8,9]$. However, as emphasized by Morowatisharifabad et al. [9], their low prediction for internal control suggests that other psychological variables undoubtedly play an important role. And, in the studies conducted by Janowski et al. [1], not only the internal but also the external locus of control correlated with engagement in health-related behaviours. It should be noted, however, that the cited study used a method for analysing the health locus of control. The studies conducted by Kwissa-Gajewska and Wojtyna [28] show that positive mood was correlated with adherence to medical recommendations for diabetics.

The study conducted indicates a worrying trend - a correlation between the intensity of health-related behaviours and the need for social approval. This suggests that only the average intensity of engaging in prohealth behaviours can be both overstated and driven by a desire to present oneself in a best possible light (sic!).

Finally, significant limitations of the study conducted should be emphasized. First of all, the study groups were small, which did not enable the use of more advanced statistical analyses that could prove more complex correlations and enable generalizations. In addition, there were more girls in the group of young people with excess body weight. To sum it up, the study conducted can be a prelude to further analyses, involving both a greater research sample and an extended range of measurement tools. It is worth searching for the psychological variables that are related to engagement in health-related behaviours by people with chronic diseases. Knowledge of it would enable more effective therapeutic effects. Questionnaire studies should also be approached with caution as the responses given can be dictated by the desire to present oneself in a best possible light, or be wishful.

\section{Conclusions}

1. Young people with type 1 diabetes and people with excess body weight present a comparable, unfortunately only an average, level of health-related behaviours.

2. The respondents are dominated by strong internal control, the conviction of having influence on their own lives.

3. There was no correlation between the locus of control and health-related behaviours in the group of patients with type 1 diabetes. 
4. The sense of internal locus of control is correlated positively with pro-health behaviours among people with excess body weight - the more the respondents are convinced that they have control over their own lives, the more often they declare engaging in health-related behaviours.

5. Both groups revealed correlation between the Lie Scale and the general indicator of health-related behaviours. Such results suggest that the respondents probably tried to present themselves in a best possible light and the outcomes obtained, not higher than average, can be overstated, as compared with the actual level of health-related behaviours.

\section{Conflict of interest}

Authors do not report any conflict of interest.

\section{REFERENCES}

1. Janowski K, Kurpas D, Kusz J, Mroczek B, Jedynak T. Health-Related Behavior, Profile of Health Locus of Control and Acceptance of Illness in Patients Suffering from Chronic Somatic Diseases. PLoS ONE 2013; 8: 2-8.

2. Larsen PD. Chronicity. In: Lubkin IM, Larsen P (ed.). Chronic illness. Impact and interwention. Jones \& Bartlett Learning, Burlington 2013: 3-22

3. Macrodimitris SD, Endler NS. Coping, control, and adjustment in Type 2 diabetes. Health Psychol 2001; 20: 208-216.

4. Tatoń J, Czech A. Diabetologia. Vol. 1. PZWL, Warszawa 2001.

5. Mućko P, Kokoszka A, Skłodowska Z. Porównanie stylów radzenia sobie z chorobą, występowania objawów depresyjnych i lękowych oraz lokalizacji poczucia kontroli u chorych na cukrzycę typu 1 i 2. Diabetol Prakt 2005; 6: 240-249.

6. Gillibrand R, Stevenson J. The extended health belief model applied to the experience of diabetes in young people. Br J Health Psychol 2006; 11: 155-169.

7. Trento $M$, Tomelini $M$, Basile $M$ et al. The locus of control in patients with type 1 and type 2 diabetes managed by individual and group care. Diabet Med 2008, 25: 86-90.

8. O'Hea EL, Moon S, Grothe KB et al. The interaction of locus of control, self-efficacy, and outcome expectancy in relation to $\mathrm{HbA} 1 \mathrm{c}$ in medically underserved individuals with type 2 diabetes. J Behav Med 2009, 32: 106-117.

9. Morowatisharifabad MA, Mahmoodabad SSM, Baghianimoghadam $\mathrm{MH}$ et al. Relationships between locus of control and adherence to diabetes regimen in a sample of Iranians. Int J of Diabetes DEV C 2010; 30: 27-32. doi:10.4103/0973-3930.60009.

10. Heszen I, Sęk H. Psychologia zdrowia. Wydawnictwo Naukowe PWN, Warszawa 2007.
11. Helmer SM, Kramer A, Mikolajczyk RT. Health-related locus of control and health behaviour among university students in North Rhine Westphalia, Germany. BMC Res Notes 2012; 5: 703.

12. Berglund $E$, Lytsy $P$, Westerling $R$. The influence of locus of control on self-rated health in context of chronic disease: a structural equation modeling approach in a cross sectional study BMC Public Health 2014; 14: 492 doi:10.1186/1471-2458-14-492.

13. Drwal RŁ. Opracowanie kwestionariusza Delta do pomiaru poczucia kontroli. Studia Psychologiczne 1979; XVIII/I: 67-83.

14. Drwal RŁ. Poczucie kontroli jako wymiar osobowości - podstawy teoretyczne, techniki badawcze i wyniki badań. In: Drwal RŁ (ed.). Adaptacja kwestionariuszy osobowości. Wydawnictwo Naukowe PWN, Warszawa 1995: 199-226.

15. Łuszczyńska A. Zmiana zachowań zdrowotnych. GWP, Gdańsk 2004.

16. Ogińska-Bulik N, Juczyński Z. Osobowość, stres a zdrowie. Difin, Warszawa 2010: 45-221.

17. Miniszewska J, Juczyński Z, Ograczyk A, Zalewska A. Health-related Quality of Life in Psoriasis: Important Role of Personal. Resources Acta Derm Venereol 2013; 93: 551-556.

18. Juczyński Z, Ogińska-Bulik N. Narzędzia pomiaru stresu i radzenia sobie ze stresem. Pracownia Testów Psychologicznych, Warszawa 2009.

19. Marteau TM, Hollands GJ, Fletcher PC. Changing human behavior to prevent disease: the importance of targeting automatic processes. Science 2012; 337: 1492-1495.

20. Bogg T, Roberts BW. Conscientiousness and health-related behaviors: a meta-analysis of the leading behavioral contributors to mortality. Psychol Bull 2004; 130: 887-919.

21. Burke $V$, Zhao $Y$, Lee $A H$ et al. Health-related behaviours as predictors of mortality and morbidity in Australian Aborigines. Prev Med 2007; 44: 135-142.

22. Juczyński Z. Narzędzia pomiaru w promocji i psychologii zdrowia. Pracownia Testów Psychologicznych, Warszawa 2001.

23. Zadworna-Cieślak M, Ogińska-Bulik N. Zachowania zdrowotne młodzieży - uwarunkowania podmiotowe i rodzinne. Wydawnictwo Difin, Warszawa 2011

24. Jodkowska M, Oblacińska A, Tabak I et al. Differences in dietary patterns in overweight and normal-weight adolescents. Med Wieku Rozw 2011; 15: 266-273.

25. Stankiewicz M, Pieszko M, Śliwińska A et al. Występowanie nadwagi i otyłości oraz wiedza i zachowania zdrowotne dzieci i młodzieży małych miast i wsi - wyniki badania Polskiego Projektu 400 Miast. Endokrynol Otyłość 2012; 6: 59-66.

26. Małkowska-Szkutnik A, Gajewski J, Mazur J et al. Predykatory poczucia własnej wartości nastolatków z cukrzycą. Med Wieku Rozw 2012; 16: 35-46.

27. Ogińska-Bulik N. Jeśli zamierzasz schudnąć. Programy oddziaływań psychologicznych wspomagających redukcję nadwagi. Wydawnictwo Wyższej Szkoły Humanistycznej w Łodzi, Łódź 1999.

28. Kwissa-Gajewska Z, Wojtyna E. Czy nadzieja sprzyja zdrowiu? Nadzieja i radzenie sobie ze stresem a stan zdrowia oraz podejmowanie zachowań zdrowotnych u chorych na cukrzycę typu 2. In: Heszen I, Życińska J. Psychologia zdrowia. W poszukiwaniu nowych inspiracji. SWPS, Warszawa 2008: 39-52. 